\title{
Utilization of soil residual phosphorus and internal reuse of phosphorus by crops
}

\author{
Mei Yang ${ }^{1}$, Huimin Yang ${ }^{\text {Corresp. } 1}$ \\ 1 State Key Laboratory of Grassland Agro-ecosystems; Key Laboratory of Grassland Livestock Industry Innovation, Ministry of Agriculture and Rural Affairs; \\ College of Pastoral Agriculture Science and Technology, Lanzhou University, Lanzhou, P. R. China, Lanzhou, Gansu, China \\ Corresponding Author: Huimin Yang \\ Email address: huimyang@|zu.edu.cn
}

Phosphorus (P) participates in various assimilatory and metabolic processes in plants. Agricultural systems are facing $P$ deficiency in many areas worldwide, while global $P$ demand is increasing. Pioneering efforts have made us better understand the more complete use of residual $P$ in soils and the link connecting plant $P$ resorption to soil $P$ deficiency, which will help to address the challenging issue of P deficiency. We summarized the state of soil "residual P" and the mechanisms of utilizing this P pool, the possible effects of planting and tillage patterns, various fertilization management practices and phosphate-solubilizing microorganisms on the release of soil residual $P$ and the link connecting leaf $P$ resorption to soil $P$ deficiency and the regulatory mechanisms of leaf $P$ resorption. The utilization of soil residual $P$ represents a great challenge and a good chance to manage $P$ well in agricultural systems. In production practices, the combination of "optimal fertilization and agronomic measures" can be adopted to utilize residual $P$ in soils. Some agricultural practices, such as reduced or no tillage, crop rotation, stubble retention and utilization of biofertilizers-phosphate-solubilizing microorganisms should greatly improve the conversion of various $P$ forms in the soil due to changes in the balance of individual nutrients in the soil or due to improvements in the phosphatase profile and activity in the soil. Leaf $\mathrm{P}$ resorption makes the plant less dependent on soil $\mathrm{P}$ availability, which can promote the use efficiency of plant $\mathrm{P}$ and enhance the adaptability to P-deficient environments. This idea provides new options for helping to ameliorate the global $P$ dilemma. 
1 Utilization of soil residual phosphorus and internal 2 reuse of phosphorus by crops

3

4

5

Mei Yang, Huimin Yang

State Key Laboratory of Grassland Agro-ecosystems; Key Laboratory of Grassland Livestock Industry Innovation, Ministry of Agriculture and Rural Affairs; College of Pastoral Agriculture Science and Technology, Lanzhou University, Lanzhou, 730020, P. R. China

Corresponding Author:

Huimin Yang

Email address: huimyang@lzu.edu.cn

\section{ABSTRACT}

Phosphorus (P) participates in various assimilatory and metabolic processes in plants. Agricultural systems are facing $\mathrm{P}$ deficiency in many areas worldwide, while global $\mathrm{P}$ demand is increasing. Pioneering efforts have made us better understand the more complete use of residual $\mathrm{P}$ in soils and the link connecting plant $\mathrm{P}$ resorption to soil $\mathrm{P}$ deficiency, which will help to address the challenging issue of $\mathrm{P}$ deficiency. We summarized the state of soil "residual $\mathrm{P}$ " and the mechanisms of utilizing this $\mathrm{P}$ pool, the possible effects of planting and tillage patterns, various fertilization management practices and phosphate-solubilizing microorganisms on the release of soil residual $\mathrm{P}$ and the link connecting leaf $\mathrm{P}$ resorption to soil $\mathrm{P}$ deficiency and the regulatory mechanisms of leaf $\mathrm{P}$ resorption. The utilization of soil residual $\mathrm{P}$ represents a great challenge and a good chance to manage $\mathrm{P}$ well in agricultural systems. In production practices, the combination of "optimal fertilization and agronomic measures" can be adopted to utilize residual $\mathrm{P}$ in soils. Some agricultural practices, such as reduced or no tillage, crop rotation, stubble retention and utilization of biofertilizers-phosphate-solubilizing microorganisms should greatly improve the conversion of various $\mathrm{P}$ forms in the soil due to changes in the balance of individual nutrients in the soil or due to improvements in the phosphatase profile and activity in the soil. Leaf $\mathrm{P}$ resorption makes the plant less dependent on soil $\mathrm{P}$ availability, which can promote the use efficiency of plant $\mathrm{P}$ and enhance the adaptability to P-deficient environments. This idea provides new options for helping to ameliorate the global P dilemma.

Keywords: $\mathrm{P}$ cycle; soil residual $\mathrm{P}$; phosphate-solubilizing microorganism; leaf $\mathrm{P}$ resorption; agricultural system; P management

\section{INTRODUCTION}

Phosphorus (P), a key component of nucleic acids, phospholipids and adenosine triphosphate (ATP), participates in various assimilatory and metabolic processes in plants (Rawat et al., 
2020). Plant growth and productivity are limited by soil P availability, which ultimately affects material circulation and function of ecosystems (Agren et al., 2012). P deficiency has adverse impacts on plant growth and productivity and may readily occur in various ecosystems especially those of agricultural systems. Around $67 \%$ of the world's agricultural land is P-deficient (Dhillon et al., 2017) and 51\% in China (Wang, 2016). The use of traditional manure alone can no longer sufficiently supplement $\mathrm{P}$ consumption in these production systems. Therefore, large amounts of $\mathrm{P}$ fertilizer have been applied to meet the increasing $\mathrm{P}$ demand. However, mined $\mathrm{P}$ is a nonrenewable resource. Based on the data released by the U.S. Geological Survey in 2017, statically calculated according to the $\mathrm{P}$ consumption rate of 2016, the verified global reserve of phosphate ore can meet the global demand of 300 years (USGS, 2016). For an extensive phosphate resource-consuming country, such as China, whose resource guarantee life is only 37 years according to the current production rate, the problem of $\mathrm{P}$ resource crisis still exists (Zhang et al., 2017). In addition, excess use of $\mathrm{P}$ fertilizer has led to the transfer of most $\mathrm{P}$ from terrestrial ecosystems into aquatic systems. The reimport of $\mathrm{P}$ back to the terrestrial ecosystems is a long and complex process with little human control. It takes nearly a million years for the $\mathrm{P}$ in marine sediment to participate in the $\mathrm{P}$ cycle of the terrestrial ecosystems again as phosphate rock (Cordell et al., 2009). Therefore, to address P deficiency, it is vital to manage P fertilization efficiently and increase $\mathrm{P}$ use efficiency in agricultural systems.

The global population explosion and increased demands for meat and dairy products have further aggravated $\mathrm{P}$ consumption in the 21 st century, which has led to increased severity of $\mathrm{P}$ deficiency in terms of global production (Ashley et al., 2011; Cordell et al., 2011). Significant advances have been made in revealing $\mathrm{P}$ dynamics at the plant, ecosystem and global scales in the past few decades, with particular advancements in understanding the effects of fertilizer applications on $\mathrm{P}$ dynamics and the $\mathrm{P}$ cycle in terms of plant-soil integration (Carpenter and Bennett, 2011; Venterink, 2011). These pioneering efforts grant us chances to integrate the information and better understand more comprehensively the use of residual $\mathrm{P}$ in the soil and the link connecting plant $\mathrm{P}$ resorption to soil $\mathrm{P}$ deficiency, which will help in addressing the challenging issue of $\mathrm{P}$ deficiency. Here, we summarized the state of mechanisms related to the use of soil residual $\mathrm{P}$ and the internal reuse of $\mathrm{P}$ by plants (Figure 1), which will help solve the contradiction between P deficiency and increased P demand (Carpenter and Bennett, 2011).

\section{SURVEY METHODOLOGY}

The peer-reviewed articles in this paper were obtained from Web of Knowledge, Google Scholar, Baidu Scholar and subject-specific professional websites, scanning also in the corresponding references, selected papers, and related articles. We employed the following keywords: "phosphorus cycle", "soil residual phosphorus", "leaf phosphorus resorption", "agricultural system", "phosphate-solubilizing microorganism" and "phosphorus management". All the articles chosen in this paper should show the state of soil "residual P" and the mechanisms of utilizing this $\mathrm{P}$ pool, the possible effects of planting and tillage patterns and various fertilization management practices on the release of soil residual $\mathrm{P}$ and the link connecting leaf $\mathrm{P}$ resorption 
80

81

82

83

84

85

86

87

88

89

90

91

92

93

94

95

96

97

98

99

100

101

102

103

104

105

106

107

108

109

110

111

112

113

114

115

116

117

118

to soil $\mathrm{P}$ deficiency and the regulatory mechanisms of leaf $\mathrm{P}$ resorption. Both qualitative and quantitative articles were reviewed in this paper. The qualitative articles provide insights into problems by helping to understand the reasons and opinions. The quantitative articles use measurable data to express facts.

\section{UTILIZATION OF SOIL RESIDUAL P AND ITS REGULATION "Residual P" in soils}

Generally, P in parent material enters the soil through weathering, is absorbed and stored by plants, and ultimately is returned to the soil in the form of litter (or metabolites produced by animals) (Foster et al., 2006). A P cycle involving utilization and transportation among plants, animals, the soil and microorganisms are formed (Aerts and Chapin, 2000). However, in terrestrial ecosystems such as agricultural systems, great amounts of $\mathrm{P}$ enter into aquatic systems, and it is difficult for this $\mathrm{P}$ to re-enter the effective $\mathrm{P}$ cycle in the short term (Cordell et al., 2009). In these cases, the cycle is broken, and P deficiency can occur, seriously affecting plant growth and productivity. Therefore, $\mathrm{P}$ fertilizer application serves as an efficient way to supplement $\mathrm{P}$, which can help to maintain and even promote the productivity of agricultural production systems (Smit et al., 2009). However, P is easily absorbed and settles in the form of organic and/or inorganic $\mathrm{P}$ with different stabilities, when soluble $\mathrm{P}$ components perform covalent bonds or electrostatic interactions with soil particles, or convert to insoluble forms by precipitation. And this accumulated $\mathrm{P}$ in the soil is difficult to convert into soluble P for plant absorption and utilization (Sattari et al., 2012; Nash et al., 2014). P fertilizer has long been overused in the farming system for decades to meet the $\mathrm{P}$ demand of crop growth because there is a traditional concept that the fixation of $\mathrm{P}$ in soils is irreversible, which results in a large $\mathrm{P}$ accumulation in the soil and ineffective utilization of P (Smit et al., 2009). Crops absorb only $20 \%$ to $30 \%$ of inorganic orthophosphate-P in most soils after P fertilization, and the remaining $\mathrm{P}$ applied is rapidly fixed (Herrera-Estrella and López-Arredondo, 2016). Mclaren et al. (2016) demonstrated that the majority of the $\mathrm{P}$ fertilizer applied to two pasture soils in Australia was absorbed in inorganic and organic $\mathrm{P}$ forms, while only $35 \%$ was taken up by subterranean clover (Trifolium subterraneum) in the year of application. A very small portion of the $\mathrm{P}$ added to the soil by fertilizer, manure and/or crop stubble is used by crops the same year it is applied (Calloway, 2016). In contrast, a varying but often substantial portion accumulates in the soil as "residual P" (Syers et al., 2008), which is defined as the difference between P input (mineral fertilizer, manure, weathering, and deposition) and $\mathrm{P}$ output (withdrawal of $\mathrm{P}$ in harvested products, and P loss by runoff or erosion) in the soil (Bouwman et al., 2009; Sattari et al., 2012). Soil inorganic P stocks constitute on average $1006 \pm 115 \mathrm{~kg} \mathrm{ha}^{-1}$, while monoester P constitutes approximately $587 \pm 32 \mathrm{~kg} \mathrm{ha}^{-1}$ (Menezes-Blackburn et al., 2018), indicating the enormous potential for future agronomic use. 
119 Fixed P in the soil can be converted into available P for plant use, and the recycling rate is up to
$12090 \%$ in some cases (Smit et al., 2009). However, there is obvious hysteresis in the use of soil

120

121

122

123

124

125

126

127

128

129

130

131

132

133

134

135

136

137

138

139

140

141

142

143

144

145

146

147

148

149

150

151

152

153

154

155

156

157

158 residual P (Sattari et al., 2012). Most of the soil residual P has undergone deposition and solidification in the formation process and is ultimately fixed in different inorganic $\mathrm{P}$ forms. Generally, $\mathrm{P}$ is adsorbed mainly by oxides and hydroxides containing iron and aluminium, resulting in the formation of an iron-aluminium binding state of $\mathrm{P}$ in acidic soils (Arai and Sparks, 2007). In neutral and calcareous soils, P mostly reacts with calcium carbonate to form more stable forms such as calcium phosphate and hydroxyapatite (Nriagu and Moore, 2012). These forms of fixed residual $\mathrm{P}$ can be absorbed and utilized by plants only after they are hydrolysed into orthophosphate in the soil solution (Ashley et al., 2011).

Therefore, it is fundamental in the utilization of residual $\mathrm{P}$ to promote the hydrolysis of soil calcium (magnesium) and/or iron (aluminium) phosphate. Existing utilization mechanisms of inorganic residual P might be divided into the following categories: 1) Direct acidification of the soil surroundings. Arai and Sparks (2007) found that rhizosphere acidification was an effective way to help obtain mobile P from calcareous soils. Additionally, the organic acids (like citric acid, gluconic acid, oxalic acid, and tartaric acid) (Rawat et al., 2020), inorganic acids (like hydrochloric acid, sulfuric acid, nitric acid, and carbonic acid) and $\mathrm{H}_{2} \mathrm{~S}$ production by phosphatesolubilizing microorganisms have been reported to solubilize inorganic phosphate, although inorganic acids have low efficiency compared to organic acids (Gaind, 2016). 2) The cationanion exchange balance, organic anion and proton extrusion, which lower soil $\mathrm{pH}$ to dissolve insoluble phosphates. Hinsinger et al. (2003) found that the cation-anion exchange balance and organic anion contributed to $\mathrm{pH}$ change in the rhizosphere since they all needed to be balanced by an exchange of charges, e.g. by the release of either $\mathrm{H}^{+}$or $\mathrm{OH}^{-}$. Proton extrusion is also an alternative mode of $\mathrm{P}$ dissolution in the soil by microorganisms, e.g. ammonium $\left(\mathrm{NH}^{+}\right)($Gaind, 2016). 3) Root exudation and assimilation/respiration, which lead to the decrease of rhizosphere $\mathrm{pH}$ in neutral to alkaline soils (Hinsinger et al., 2003). 4) Direct redox-coupled reaction. Plant roots and associated microorganisms can also alter the $\mathrm{pH}$ of the rhizosphere via redox-coupled reactions, thereby improving the availability of residual P in the soils (Hinsinger et al., 2003). For instance, predominantly gram-negative bacteria can help the production of dominant organic acids like gluconic acid via alternative pathways for glucose oxidation and diffuse through bacterial periplasm into the surroundings (Krishnaraj and Dahale, 2014). 5) Production of siderophore by phosphate-solubilizing microorganisms (PSMs), which can be a strategy to chelate iron from Fe-P complexes in the soil. Toscano-Verduzco et al. (2019) found that a novel fungus, Beauveria brongniartii, secreted siderophores, which resulted in $59.8 \%$ of $\mathrm{Fe}^{3+}$-Chrome azurol-S degradation and $158.95 \mathrm{mg} \mathrm{L} \mathrm{L}^{-1} \mathrm{P}$ solubilized in vitro. 6) Production of exopolysaccharide, which forms complexes with metal ions in the soil $\left(\mathrm{Al}^{3+}>\mathrm{Cu}^{2+}>\mathrm{Zn}^{2+}>\mathrm{Fe}^{3+}>\mathrm{Mg}^{2+}>\mathrm{K}^{+}\right)$(Ochoa-Loza et al., 2001). This mechanism can be extrapolated as a means of $\mathrm{P}$ solubilization by exopolysaccharide-secreting microorganisms. Additionally, microbial cell lysis during stress conditions releases this $\mathrm{P}$ into the soil, which is taken up by plants and other soil organisms (Butterly et al., 2009).

Peer) reviewing PDF | (2021:01:56829:2:0:NEW 23 May 2021) 


\section{Utilization of organic residual $P$ in soils}

161

162

163

164

165

166

167

168

169

170

171

172

173

174

175

176

177

178

179

180

181

182

183

184

185

186

187

188

189

190

191

192

193

194

195

196

197

198

The utilization of organic $\mathrm{P}$ also plays a major role in the use of soil residual $\mathrm{P}$. Organic $\mathrm{P}$ in soils generally accounts for $20 \%-30 \%$ of the total residual $\mathrm{P}$ and in some cases accounts for $95 \%$ (Rawat et al., 2020). The vast majority of soil organic $\mathrm{P}$ is held by a single or double lipid bond, which can be divided into inositol (mainly from plant residue), nucleic acid (from plant and soil organism residue) and phospholipid (from plant, soil animal and microbial residue) forms (Betencourt et al., 2012).

The conversion from organic $\mathrm{P}$ to available $\mathrm{P}$ in soils is largely controlled by phosphatase catalysis and hydrolysis (Kumar and Shastri, 2017). These extracellular phosphatases produced by microorganisms and plant roots mostly belong to non-specific acidic phosphatases, and can catalyze the dephosphorylation of phosphoesters or phosphoanhydride bonds of organic compounds to promote the degradation of organic P complexes (Sharma et al., 2013), thereby driving the continuous P cycle between microbial fixation and release (Richardson et al., 2011). However, it remains unclear how much microorganisms, plant roots and other soil organisms contribute to the release of the residual $\mathrm{P}$ in soils (Gaiero et al., 2018). Generally, microorganisms (including bacteria, fungi and actinomycetes) produce acidic and alkaline phosphatases, while plants produce only acidic phosphatases (Nannipieri et al., 2011). For instance, fungi such as ectomycorrhizae are well known for their ability to secrete acidic phosphatases, and associated plants can thus grow well with improved $\mathrm{P}$ availability (Rosling et al., 2016). Acidic soils are dominated by acidic phosphatases, while alkaline soils are dominated by alkaline phosphatases (Juma and Tabatabai, 1977). The ability of alkaline phosphatases to break down substrates under alkaline conditions is obviously greater than that under neutral and acidic conditions.

Non-specific acidic phosphatases like acidic and alkaline phosphatases are typical inducible enzymes and their activity are readily affected by P supply levels. Hofmann et al. (2016) showed that the activity of acidic and alkaline phosphatases in rhizosphere soils was $27 \%-53 \%$ higher in P-deficient areas than in P-rich areas of Fagus sylvatica forests. Further, they found that at low P availability, acidic phosphatase activity increased in the rhizosphere but not in the bulk soil, and microbial phosphatase activity was not responsive to P fertilization and was still high in the Prich soil. These results suggested that compared with microbial phosphatase, plant acidic phosphatase activity may increase more at P-deficient sites, and microbial phosphatases contributed more to total phosphatase activity than plant phosphatases in the P-rich soil (Hofmann et al., 2016). That is probably because phosphatase activity is regulated not only by $\mathrm{P}$ but also by $\mathrm{C}$ availability. The microbial phosphatases activity would increase to mineralize organic phosphorylated compounds extracellularly and the organic fraction of the compound can be used as a C source (Heuck et al., 2015). In practice, microbial inoculation of plant roots can not only prevent pathogens but also induce rapid soil $\mathrm{P}$ cycle and reduce $\mathrm{P}$ fixation, which thus enhances P fertilizer utilization in agricultural systems (Richardson et al., 2011; Li et al., 2018). For instance, tomato (Solanum lycopersicum) under low-P conditions inoculated with 
199

200

201

202

203

204

205

206

207

208

209

210

211

212

213

214

215

216

217

218

219

220

221

222

223

224

225

226

227

228

229

230

231

232

233

234

235

236

237

238

Pseudomonas sp. RU47 primarily increase their microbial phosphatase activity in soils and stimulate the enzymatic cleavage of organic P compounds in rhizosphere and bulk soil, which promotes plant growth and utilization efficiency of $\mathrm{P}$ fertilizer in agricultural systems (Nassal et al., 2018). Sundara et al. (2002) also reported a 25\% decrease in the P requirement of sugarcane (Saccharum hybrid) when P fertilizer was used in combination with the P-solubilizing bacterium Bacillus megaterium var. phosphaticum.

Phytases widely found in animals, plants and microorganisms, can catalyze the removal of $\mathrm{P}$ from the phytate compounds (abundant organic P in soils) that is the dominant source of inositol and stored $\mathrm{P}$ in seeds and pollen (Sharma et al., 2013). Compared to plants and animals, the potential of phytase producing bacteria and fungi to obtain $\mathrm{P}$ from phytates is very huge (Zineb et al., 2019). Besides, phosphatases /carbon-phosphorus (C-P) lyases can also catalyze the cleavage of the $\mathrm{C}-\mathrm{P}$ bond of organophosphates, improving the $\mathrm{P}$ availability to plants (Rodriguez et al., 2007). Some studies have focused on revealing the function and mechanism of soil microorganisms involved in soil $\mathrm{C}$ mineralization to improve soil organic $\mathrm{P}$ mineralization (Nuccio, 2014).

\section{Regulation of the release of residual $P$ in soils}

Multiple different tillage and management practices are beneficial for improving the release of soil residual $\mathrm{P}$ in production practices to strengthen the activity of soil phosphates and acidify soil rhizosphere (Figure 1). This will ultimately promote the use of residual $\mathrm{P}$ and reduce the dependence of crops on $\mathrm{P}$ fertilization.

\section{Planting and tillage pattern}

Intercropping and crop rotation can reduce the competition for soil $\mathrm{P}$ between plants due to increased plant diversity, and enhance the utilization of soil original residual $\mathrm{P}$ and newly accumulated organic P (Garland et al., 2017), mainly through more organic acid and phosphatase secretion. Darch et al. (2018) found that barley (Hordeum vulgare)/legume intercropping led to $10 \%-70 \%$ greater $\mathrm{P}$ accumulation and $0-40 \%$ greater biomass than monocultures in a pot trial. The difference in the release patterns of organic acids and phosphatases by different species in the two systems may partly explain the results. More organic acid and phosphatase release can effectively increase the activation of soil residual $\mathrm{P}$ (Hinsinger et al., 2011; Darch et al., 2018). Compared with that under monocultures, acid phosphatase secretion under wheat (Triticum aestivum)/soybean (Glycine max) or wheat/corn (Zea mays) intercropping would increase, which potentially improves the use efficiency of residual $\mathrm{P}$ in soils (Zhang, 2001). In addition, soil phosphatase activity significantly increases under long-term alfalfa (Medicago sativa)-potato (Solanum tuberosum)-wheat rotation compared with fallow systems in the dryland areas on the Loess Plateau of China (Fan and Hao, 2003). Straw return after rotation reduces the $\mathrm{P}$ fixation rate in soils to improve soil $\mathrm{P}$ availability (Calonego and Rosolem, 2013). Hallama et al., (2019) stated that cover cropping strengthened nutrient cycling in agricultural systems under different conditions, increasing crop P nutrition 
239

240

241

242

243

244

245

246

247

248

249

250

251

252

253

254

255

256

257

258

259

260

261

262

263

264

265

266

267

268

269

270

271

272

273

274

275

276

277

278

and yield, as this practice could enhance soil microbial communities. Additionally, the phosphatase activity under reduced tillage is higher than that under traditional tillage (Monreal and Bergstrom, 2000). The promotion of phosphatase activity leads to increased release of soil residual $\mathrm{P}$ and an increase in soil $\mathrm{P}$ availability. In the rhizosphere acidification to get soil inorganic residual $\mathrm{P}$, we might grow crops, e.g. white lupin (Lupinus albus) (Dinkelaker et al., 2010) which can release organic acids, such as citric, oxalic and malic acids (Jones et al., 2002). The cereals allocated more photosynthates to below-ground parts, e.g. maize (Urte et al., 2013) or wheat, also increase root exudation and respiration to acidify soil rhizosphere (Hans and Frank, 2002). And the crops root-induced oxidation of Fe can decrease rhizosphere $\mathrm{pH}$ by redoxcoupled process (Chen et al., 1980), e.g. wetland plants and lowland rice (Oryza sativa L.) (Ando et al., 1983). In general, compared with monocultures, crop rotation and intercropping significantly promote the release and utilization of residual $\mathrm{P}$ in soils. Although Tang et al. (2015) found that compared with tobacco (Nicotiana tabacum) / garlic (Allium sativum) intercropping, the tobacco - garlic rotation could better activate O-P, $\mathrm{Ca}_{10}-\mathrm{P}$ and resistant organic $\mathrm{P}$ in soils. There are few studies comparing crop rotation and intercropping, and there is no consistent conclusion since the effects of intercropping and crop rotation on the utilization of soil residual $\mathrm{P}$ were different with different fertilization or co-cropped species (Githinji et al., 2011; Yong et al., 2014; Djuniwati and Pulunggono, 2019).

\section{Fertilization management}

$\mathrm{P}$ fertilizer has long been applied to maintain high soluble $\mathrm{P}$ concentration in soils in production practices, although most of the $\mathrm{P}$ fertilizer is fixed only three hours after application (Chang and $C h u, 1961)$. The combined application of $\mathrm{P}$ fertilizer with other fertilizers can not only improve total soil fertility but also promote the use of residual P in soils. Several reasons may explain the $\mathrm{P}$ availability increase in soils after mixed fertilizer application. The application of multiple inorganic fertilizers balances the individual nutrients and each form of the same nutrient, which helps to regulate the transformation between Ca-P systems and A1-P (Fe-P) systems. This significantly increases the available inorganic $\mathrm{P}$ accumulation and improves the $\mathrm{P}$ availability in soils. Combinations with $\mathrm{N}$ or organic fertilizers lead to soil acidity or a change in phosphatase activity, which consequently enhances soil residual $P$ release to improve $P$ availability.

Long-term $\mathrm{N}$ and $\mathrm{P}$ fertilizer application causes soil acidification, which increases the available $\mathrm{P}$ level in calcareous soils. The increase in soil $\mathrm{P}$ availability under $\mathrm{N}$ or $\mathrm{N}$ plus $\mathrm{P}$ fertilization can also be the result of increased phosphatase activity induced by $\mathrm{N}$ (Wang et al., 2007; Peñuelas et al., 2012). Compared to the sole fertilizer applications, soil enzyme activity, microorganisms or organic $\mathrm{P}$ content would increase in response to applications of inorganic fertilizer combined with organic fertilizer (Ahlgren, et al., 2013). However, P fertilizer alone hardly affects the secretion of acidic phosphatase in non-rhizosphere soils but reduces the acidic phosphatase activity in rhizosphere soils (Spohn et al., 2013).

The application of organic fertilizers can not only increase the available P content but also improve residual $\mathrm{P}$ release in soils. Supply of organic matter from organic $\mathrm{P}$ fertilization to 
279 upland soil has been reported to decrease P-sorption and increase P desorption. This is mainly 280 because organic and/or inorganic anion can compete with orthophosphate for the presence in the 281 soil, leading to increase in $\mathrm{P}$ availability. While mineral $\mathrm{P}$ fertilization generally provides more 282 reactive $\mathrm{Al}$ and Fe into the soil, and fixes more $\mathrm{P}$ (Djuniwati and Pulunggono, 2019). The single283 lipid $\mathrm{P}$ content in soils increases after the application of various types of manure in practice 284 (Shafqat et al., 2009), and the combination of manure and mineral P fertilizer also significantly 285 increases the orthophosphate portion of soil P (Ahlgren et al., 2013). Organic fertilizer contains a 286 large number of highly active acidic phosphatases and soil microorganisms, and these 287 microorganisms can also greatly increase the activity of acidic phosphatase. Neset et al. (2008) 288 found that the activities of acidic phosphatase, alkaline phosphatase, phosphodiesterase and 289 pyrophosphatase in animal waste (which can be used as organic fertilizer) were 10, 45, 50 and 290 291

292

293

294

295

296

297

298

299

300

301

302

303

304

305

306

307

308

309

310

311

312

313

314

315

316

317

318

160 times higher than that in soils. This activity will greatly help catalyze soil organic $\mathrm{P}$ in the soil, improving soil $\mathrm{P}$ availability. In addition, stubble is one of the most important sources of organic fertilizer in conservation agricultural systems. The return of stubble can directly increase soil $\mathrm{P}$ amount and help to improve residual $\mathrm{P}$ release. Compared with the removal of aboveground parts, the return leads to $31 \%-63 \%$ increase in the contents of soluble $\mathrm{P}$, unstable organic $\mathrm{P}$ and total $\mathrm{P}$ in soils in mixture grassland of red clover (T. pratense), white clover ( $T$. repens), perennial ryegrass (Lolium perenne) and cocksfoot (Dactylis glomerata) (Boitt et al., 2017). Zhan et al. (2015) found that the activities of acidic, neutral and alkaline phosphatases and soil available $\mathrm{P}$ content with rice straw mulching were significantly higher than those without mulching. Notably, in natural systems, plant litter is the main source of organic $\mathrm{P}$ and acts as a stubble return to drive the $\mathrm{P}$ cycle (Jiang et al., 2013). In addition, phosphatase activity is also regulated by C availability in soils (Steenbergh et al., 2011). Hofmann et al. (2016) found that microorganisms could use the organic part of phosphates as a $\mathrm{C}$ source to enhance the secretion of phosphatases. Given these advantages, organic fertilizer application constitutes a preferred method for agricultural production to meet $P$ requirements.

\section{Utilization of biofertilizer}

Phosphate-solubilizing microorganisms are bioinoculants that are promising substitutes for agrochemicals, which adopts different strategies to solubilize insoluble $\mathrm{P}$ to soluble forms and can reduce the phosphate fertilizer input in agricultural land (Hussain et al., 2019). Generally, bacteria belonging to the genera Pseudomonas, Enterobacter, Bacillus (Biswas et al., 2018), Rhizobium, Arthrobacter, Burkholderia, and Rahnella aquatilis HX2 (Liu et al., 2019), Leclercia adecarboxylata and fungi like Penicillium brevicompactum and Aspergillus niger (Rojas et al., 2018) as well as Acremonium, Hymenella and Neosartorya (Ichriani et al., 2018) are all potent phosphate-solubilizing microorganisms. Recently, Astriani et al. (2020) have discovered novel elite strains like Pseudomonas plecoglossicida isolated from soybean rhizosphere, which solubilized $75.39 \mathrm{mg} \mathrm{L}^{-1} \mathrm{P}$ and produced plant hormones, for instance indole acetic acid concentration was up to $38.89 \mathrm{ppm}$. These microorganisms serve as potent biofertilizers that improve the agricultural yield in harmony with ecological concerns.

Peer) reviewing PDF | (2021:01:56829:2:0:NEW 23 May 2021) 
In practical production, phosphate-solubilizing microorganisms are generally inoculated on the crop, added to soil, and applied together with organic/inorganic fertilizers to solubilize residual soil P to soluble forms. Martínez et al. (2015) found inoculation with phytate-producing bacteria like Enterobacter sp. N0-29PA significantly increased the biomass and P uptake of oat (Avena sativa) by changing the rhizosphere properties and soil enzyme activities (acidic phosphatase and urease) as well as auxin production potential without the use of fertilizer. In addition, phosphobacteria inoculation enhances the benefit of P fertilization. Barra et al. (2019) found the consortium of phosphobacteria (Klebsiella sp. RC3, Stenotrophomonas sp. RC5, Klebsiella sp. RC J4, Serratia sp. RC J6, and Enterobacter sp. RJAL6) with P fertilization improved $\mathrm{P}$ content in the shoot of perennial ryegrass by $29.8 \%$ compared to uninoculated control in P-deficient soils. Moreover, the addition of phosphate solubilizing bacteria such as Bacillus, Pseudomonas, Enterobacter, Acinetobacter, Rhizobium, and Burkholderia (Teng et al., 2018) as well as endophytic fungi such as Aspergillus, Penicillium, Piriformospora, and Curvularia (Mehta et al., 2019) can improve C-P lyases activity to promote the utilization of residual organic $\mathrm{P}$. The application of phosphate-solubilizing microorganisms in combination with different $\mathrm{P}$ sources and nutrients (iron, silicon) improves $\mathrm{P}$ uptake and use efficiency of the crop, consequently enhancing the growth and yield of crops. Boroumand et al. (2020) reported that phosphate-solubilizing Pseudomonas stutzeri and Mesorhizobium sp. along with nano-silica $(0.05,0.07 \mathrm{ppm})$ improved vegetative growth of land cress (Barbarea verna) and increased soil nitrogen and $\mathrm{P}$ content. This is, nano-silica might either act as a substrate for microorganisms or a stimulant that results in an increased microbial population (Karunakaran et al., 2013). The interaction of phosphate-solubilizing microorganisms (Pseudomonas, Mycobacterium, Bacillus, Pantoea Rhizobia, and Burkholderia) and phosphate fertilizer improve wheat grain yield by $22 \%$ and $\mathrm{P}$ uptake by $26 \%$, while reduce fertilizer input by $30 \%$. Moreover, these biofertilizers are safe and non-toxic to the environment (Rawat et al., 2020). In addition, transgenic technology has also been used in phosphate-solubilizing microorganisms to achieve efficient utilization of $P$ resources. Richardson. (2001) found improved $\mathrm{P}$ nutrition and growth in Arabidopsis that is genetically transformed with the phyA gene from Aspergillus niger. In recent years, metagenomics approach has also been used to modify not only phosphate-solubilizing microorganisms but also other microorganisms for improving and introducing phosphatesolubilizing efficiency (Kumar and Shastri, 2017).

Given the nonrenewable particularity of $\mathrm{P}$ resources, the utilization of mined $\mathrm{P}$ should be developed toward the way of "moderate mining and efficient utilization" in the future. During production, the combination of "optimal fertilization and agronomic measures" should be adopted to improve the utilization of residual $\mathrm{P}$ in soils to promote the use efficiency of $\mathrm{P}$ fertilizer and soil P stocks. A better understanding of residual P dynamics and its regulation by agricultural practices such as reduced tillage, crop rotation and stubble retention should help the conversion of various $\mathrm{P}$ forms in the soil, as these measures lead to changes in the balance of individual nutrients in the soil or lead to improvements in the phosphatase profile and activity in soils. The addition of organic fertilizer such as green manure also has a similar effect. Therefore, 
359 full exploration of soil residual $\mathrm{P}$ dynamics is still needed, and especially in conservation

360

361

362

363

364

365

366

367

368

369

370

371

372

373

374

375

376

377

378

379

380

381

382

383

384

385

386

387

388

389

390

391

392

393

394

395

396

397

agricultural system, the mechanisms by which conservation practices influence soil and soil microorganisms warrant further attention. Notably, in some areas, such as the Qinghai-Tibetan Plateau of China, where extremely low temperatures have heavily restricted the release and use of soil $\mathrm{P}$, the effects of cover crop change, tillage method and fertilization management also warrant deep study from the standpoint of a low-temperature background.

\section{INTERNAL REUSE OF P IN THE PLANT AND ITS REGULATION Plant $P$ resorption}

P limitation to plant growth is common in diverse ecosystems and is particularly vital for grain production due to its significant effects during the reproductive stages (Vergeer et al., 2003). When plants have difficulty acquiring sufficient $\mathrm{P}$ supplies from soils, they adjust the distribution of the limited $\mathrm{P}$ among various organs (tissues) to maintain metabolic activity, growth and survival. For instance, decreased litter nutrient content is often one of the nutrient preservation strategies for plants growing in N- and/or P-limited soils (Wright and Westoby, 2003).

Nutrient resorption refers to the process by which nutrients from senescent tissues (such as senescent leaves) are transferred to other actively growing tissues (such as green leaves and new tissues). This process can not only reallocate nutrients for the growth of new and surviving tissues of the plant (Mao et al., 2013), but also reduce the risk of nutrient loss with litterfall. Therefore, the plant can effectively maintain the productivity and exhibit enhanced stress resistance to soil nutrient deficiency, such as $\mathrm{P}$ deficiency. Retranslocation may occur in senescing leaves, stems and roots (Gordon and Jackson, 2000). In American desert shrubbery, where the soils contain a large number of carbonates with strong P fixation, Larrea tridentata growth was not limited by soil $\mathrm{P}$ because there was $72 \%-86 \% \mathrm{P}$ resorption efficiency (Lajtha, 1987). Vergutz et al. (2012) found that approximately $64.9 \%$ of $\mathrm{P}$ was transferred from senesced tissues to active tissues during plant senescence at a global scale, and Wang et al. (2014) found that leaf $P$ resorption efficiency of alfalfa varied with the growth stage. This efficiency can reach $67 \%-84 \%$ at the early flowering stage of alfalfa when forage harvest is performed ( $L u$ et al., 2019). Compared to N, P generally shows higher variability of resorption efficiency (proportion resorbed) and higher resorption sensitivity to nutrient availability, implying that $\mathrm{P}$ resorption seems more important for plant nutrient conservation and N:P stoichiometry (Staff, 2014). P resorption within the plant is very important for improving $\mathrm{P}$ use efficiency at the individual level, making the plant less dependent on soil $\mathrm{P}$ availability and more tolerant to soil $\mathrm{P}$ deficiency.

\section{Regulation of $\mathbf{P}$ resorption}

Leaf P resorption differs among different genetic origins (Sakuraba et al., 2015) and functional groups (Miao et al., 2019), and is readily affected by environmental variations (Du et al., 2017), such as soil P availability and its balance with other nutrients (stoichiometric ratio) (Tang et al., 
398

399

400

401

402

403

404

405

406

407

408

409

410

411

412

413

414

415

416

417

418

419

420

421

422

423

424

425

426

427

428

429

430

431

432

433

434

435

436

437

2013). However, the mechanisms to drive $\mathrm{P}$ resorption from senesced tissues may involve both the source-sink relationship and acidic phosphatase hydrolysis in the plant.

\section{Source-sink relationship}

The source-sink relationship of $\mathrm{P}$ plays a major role in regulating $\mathrm{P}$ resorption of the plant. Generally, senescent tissue is the $\mathrm{P}$ source, while active tissues constitute the sink (Bieleski, 1973). When the $\mathrm{P}$ content in a plant exceeds the normal demand of the variety, $\mathrm{P}$ accumulates in senesced leaves, which causes a decrease in P resorption (Uliassi and Ruess, 2002). Kobe et al. (2005) found that $\mathrm{P}$ resorption efficiency decreased with increasing $\mathrm{P}$ content in green leaves (P sink). Therefore, the change in nutrient concentrations in different organs (representing sources or sinks) is closely related to nutrient redistribution (Zhang et al., 2018). Other studies have shown that nutrient resorption efficiency is more strongly regulated by carbohydrate flux from leaves (source-sink interaction) than by factors governing the hydrolysis of nutrient-containing fractions in leaves (Aerts, 1990). Under P-deficient conditions, a decrease in carbohydrate accumulation is an important regulatory mechanism to enhance source-sink interaction, which primes nutrient transfer in the plant (Demars, 1997). Usuda. (1995) found during mature leaf blades senescence in maize, the mature leaves were still photosynthetically active but no longer grew, thus reducing the need for $\mathrm{P}$ by RNA, and $\mathrm{P}$ from nucleic acids was therefore transferred to new leaves. Meanwhile, $\mathrm{P}$ deprivation may induce the early initiation and accelerate remobilization of $\mathrm{N}$ from old leaf blades. So soil $\mathrm{P}$ deficiency does not immediately slow plant growth because $\mathrm{P}$ can be transferred from senesced leaves to sites where $\mathrm{P}$ is largely needed (Limpens et al., 2003), but leaf senescence is often accelerated by nutrient deficiency (Bollens, 2000). Thus, leaf senescence results in increased P resorption.

\section{Acidic phosphatase hydrolysis}

Acidic phosphatase can hydrolyze organic P compounds in the plant into inorganic phosphate and thus help transfer phosphate from senesced tissues to young tissues. The P content accounts for $0.05 \%-0.5 \%$ of plant dry weight (Vance et al., 2003). Most of this $\mathrm{P}$ exists in plant leaves as organic $\mathrm{P}$, including nucleic acids, phospholipids, and phosphorylated metabolites, among which ribosomal ribonucleic acid represents the largest organic $\mathrm{P}$ pool in the cell, accounting for $40 \%$ $60 \%$ of the total organic $\mathrm{P}$ in mature leaves (Veneklaas et al., 2012). Plants can hydrolyze their organic P compounds into inorganic phosphate by acidic phosphatase and help transfer the phosphate from senesced tissue to young tissue. The activity of acidic phosphatase is enhanced when $\mathrm{P}$ is deficient in soils, and $\mathrm{P}$ transportation from older organs and tissues to active sites occurs sooner under low P availability. Generally, the higher the acidic phosphatase activity is in a plant, the greater the internal reuse rate of the phosphate. A recent study has shown that purple acidic phosphatases not only help activate organic P around Arabidopsis root systems but also promote $\mathrm{P}$ utilization in the plant. These phenomena are evidenced by the fact that the AtPAP26 gene in Arabidopsis promotes P transfer in the leaf senescence process (Robinson et al., 2012). Although there are some clues that acidic phosphatase is related to $\mathrm{P}$ resorption and leaf 
475

476

senescence, the regulation of $\mathrm{P}$ transfer from senesced leaves is still far from fully understood (Veneklaas et al., 2012).

It is necessary to use the potential of a plant to maximize the $\mathrm{P}$ effectiveness. $\mathrm{P}$ resorption is an important strategy that the plant has evolved to address soil P deficiency (Kobe et al., 2005). We can use optimal species with this trait in production, e.g. evergreen tree species, to reduce the dependence on soil P and P fertilization (Fife et al., 2008). Although a relationship between acidic phosphatase and $\mathrm{P}$ resorption has been shown and the existence of acidic phosphatase genes controlling $\mathrm{P}$ transfer to regulate leaf senescence has also been ascertained, the metabolic network regulating $\mathrm{P}$ transfer in senesced leaves still needs to be revealed. A more systematic discussion of the transfer of $\mathrm{P}$ from senesced tissues and the control of $\mathrm{P}$ resorption at the molecular level should be carried out. In addition, litterfall is one of the consequences of nutrient resorption and contributes relatively large amounts of organic matter to soils, which is important in maintaining the cycles of $\mathrm{P}$ and other nutrients in diverse systems. However, the tradeoff of resorbed nutrients and the nutrition of litter need to be explored within individual plants. This idea may be one of the keys that unlock the resorption and residual $\mathrm{P}$ release.

\section{CONCLUSIONS}

We summarized the state of soil "residual P" and the mechanisms of utilizing this $\mathrm{P}$ pool. The utilization can be facilitated by the acidification of the soil surroundings, the cation-anion exchange balance, organic anion and proton extrusion, root exudation and assimilation/respiration, direct redox-coupled reactions, production of siderophore and exopolysaccharide, and other pathways to utilize inorganic residual $\mathrm{P}$ in soils. It is also promoted by plant and microorganism secreted non-specific acidic phosphatases, phytases, and phosphatases/C-P lyases to utilize organic residual $\mathrm{P}$ in soils. In addition, the phosphatesolubilizing microorganism, namely biofertilizer play an important role in the utilization of the two kinds of residual P. We also summarized the possible effects of planting and tillage patterns and various fertilization management practices on the release of soil residual $\mathrm{P}$ and the link connecting leaf $\mathrm{P}$ resorption to soil $\mathrm{P}$ deficiency and the regulatory mechanisms of leaf $\mathrm{P}$ resorption. The utilization of soil residual $\mathrm{P}$ represents a great challenge and a good chance to manage $\mathrm{P}$ well in agricultural systems. In production practices, the combination of "optimal fertilization and agronomic measures" can be adopted to utilize residual $\mathrm{P}$ in soils. Some agricultural practices, such as reduced or no tillage, crop rotation and stubble retention, should greatly improve the conversion of various $\mathrm{P}$ forms in the soil due to change in the balance of individual nutrients in the soil or due to improvements in the phosphatase profile and activity in the soil. Leaf $\mathrm{P}$ resorption makes the plant less dependent on soil $\mathrm{P}$ availability, which can promote the use efficiency of plant $\mathrm{P}$ and enhance the adaptability to P-deficient environments. This idea provides new options for helping to ameliorate the global $\mathrm{P}$ dilemma.

\section{ACKNOWLEDGEMENTS}


477 This work was jointly supported by the earmarked fund for China Agriculture Research System 478 of MOF and MARA (CARS-34) and the National Natural Science Foundation of China 479 (31572460). We appreciated very much the help from Dr. Yuan Li, Mr. Samaila Usman and 480 Nature Research Editing Service for language polishing. As Newton said, "If I have seen further, 481 it is by standing on the shoulders of giants", this work would be impossible without the previous 482 valuable research.

483

484

485

486

487

488

489

490

491

492

493

494

495

496

497

498

499

500

501

502

503

504

505

506

507

508

509

510

511

512

513

514

515

\section{REFERENCES}

Aerts R, Chapin F. 2000. The mineral nutrition in wild plants revisited: a re-evaluation of processes and pattern. Advances in Ecological Research 30(8):1-67. DOI 10.1016/S00652504(08)60016-1.

Aerts R. 1990. Nutrient use efficiency in evergreen and deciduous species from heathlands. Oecologia 84(3):391-397. DOI 10.1016/S0065-2504(08)60016-1.

Agren GORI, Wetterstedt JAM, Billberger MF. 2012. Nutrient limitation on terrestrial plant growth-modeling the interaction between nitrogen and phosphorus. New Phytologist 194(4):953-960. DOI 10.1111/j.1469-8137.2012.04116.x.

Ahlgren J, Djodjic F, Börjesson G, Mattsson L. 2013. Identification and quantification of organic phosphorus forms in soils from fertility experiments. Soil Use and Management 29(1):24-35. DOI 10.1111/sum.12014.

Ando T, Yoshida S, Nishiyama I. 1983. Nature of oxidizing power of rice roots. Plant and Soil 72(1):57-71. DOI 10.1007/BF02185094.

Arai Y, Sparks DL. 2007. Phosphate reaction dynamics in soils and soil components: a multiscale approach. Advances in Agronomy 94:135-179. DOI 10.1016/S00652113(06)94003-6.

Ashley K, Cordell D, Mavinic D. 2011. A brief history of phosphorus: from the philosopher's stone to nutrient recovery and reuse. Chemosphere 84(6):737-746. DOI 10.1016/j.chemosphere.2011.03.001.

Astriani M, Zubaidah S, Abadi AL, Suarsini E. 2020. Pseudomonas plecoglossicida as a novel bacterium for phosphate solubilizing and indole-3-acetic acid-producing from soybean rhizospheric soils of East Java, Indonesia. Biodiversitas Journal of Biological Diversity 21(2):578-586. DOI 10.13057/biodiv/d210220.

Barra PJ, Pontigo S, Delgado M, Parra-Almuna L, Mora M. 2019. Phosphobacteria inoculation enhances the benefit of P-fertilization on Lolium perenne in soils contrasting in P-availability. Soil Biology and Biochemistry, 136:107516. DOI 10.1016/j.soilbio.2019.06.012.

Betencourt E, Duputel M, Colomb B, Desclaux D, Hinsinger P. 2012. Intercropping promotes the ability of durum wheat and chickpea to increase rhizosphere phosphorus availability in a low p soil. Soil Biology and Biochemistry 46:181-190. DOI 10.1016/j.chemosphere.2011.03.001. 
516 Bieleski RL. 1973. Phosphate pools, phosphate transport and phosphate availability. Annual

517

518

519

520

521

522

523

524

525

526

527

528

529

530

531

532

533

534

535

536

537

538

539

540

541

542

543

544

545

546

547

548

549

550

551

552

553

554

555

556 Review of Plant Physiology 24(1):225-252. DOI 10.1146/annurev.pp.24.060173.001301.

Biswas JK, Banerjee A, Rai M, Naidu R, Biswas B, Vithanage M, Dash MC, Sarkar SK, Meers E. 2018. Potential application of selected metal resistant phosphate solubilizing bacteria isolated from the gut of earthworm (Metaphire posthuma) in plant growth promotion. Geoderma 330:117-124. DOI 10.1016/j.geoderma.2018.05.034.

Boitt G, Black A, Wakelin SA, Mcdowell RW, Condron LM. 2017. Impacts of long-term plant biomass management on soil phosphorus under temperate grassland. Plant and Soil 427(1-2):1-12. DOI 10.1007/s11104-017-3429-0.

Bollens U. 2000. Effects of nutrient inputs and water regime on wetland vegetation and the performance of wetland species. ETH Zurich. DOI 10.3929/ethz-a-003887336.

Boroumand N, Behbahani M, Dini G. 2020. Combined Effects of Phosphate Solubilizing Bacteria and Nanosilica on the Growth of Land Cress Plant. Journal of Soil Science and Plant Nutrition 20(1):232-243. DOI 10.1007/s42729-019-00126-8.

Bouwman AF, Beusen A, Billen G. 2009. Human alteration of the global nitrogen and phosphorus soil balances for the period 1970-2050. Global Biogeochemical Cycles 23(4):116. DOI 10.1029/2009GB003576.

Butterly CR, Bünemann EK, Mcneill AM, Baldock JA, Marschner P. 2009. Carbon pulses but not phosphorus pulses are related to decreases in microbial biomass during repeated drying and rewetting of soils. Soil Biology and Biochemistry 41(7):1406-1416. DOI 10.1016/j.soilbio.2009.03.018.

Calloway M. 2016. Feeding the world: a challenge for the twenty-first century. Electronic Green Journal 1(13):285-286. DOI 10.2307/216127.

Calonego JC, Rosolem CA. 2013. Phosphorus and potassium balance in a corn-soybean rotation under no-till and chiseling. Nutrient Cycling in Agroecosystems 96(1):123-131. DOI 10.2307/216127.

Carpenter SR, Bennett EM. 2011. Reconsideration of the planetary boundary for phosphorus. Environmental Research Letters 6(1):14009. DOI 10.1088/1748-9326/6/1/014009.

Chang SC, Chu WK. 1961. The fate of soluble phosphate applied to soils. European Journal of Soil Science 12(2):286-293. DOI 10.1111/j.1365-2389.1961.tb00918.x.

Chen CC, Dixon JB, Turner FT. 1980. Iron coatings on rice roots: mineralogy and quantity influencing factors. Soil Science Society of America Journal 44(3):635-639. DOI 10.2136/sssaj1980.03615995004400030041x.

Cordell D, Drangert J, White S. 2009. The story of phosphorus: global food security and food for thought. Global Environmental Change 19(2):292-305. DOI 10.1016/j.gloenvcha.2008.10.009.

Cordell D, Rosemarin A, Schröder JJ, Smit AL. 2011. Towards global phosphorus security: a systems framework for phosphorus recovery and reuse options. Chemosphere 84(6):47-758. DOI 10.1016/j.chemosphere.2011.02.032.

Darch T, Giles CD, Blackwell MSA, George TS, Brown LK, Menezes-Blackburn D, Shand CA, Stutter MI, Lumsdon DG, Mezeli MM. 2018. Inter-and intra-species intercropping of

Peer) reviewing PDF | (2021:01:56829:2:0:NEW 23 May 2021) 
557

558

559

560

561

562

563

564

565

566

567

568

569

570

571

572

573

574

575

576

577

578

579

580

581

582

583

584

585

586

587

588

589

590

591

592

593

594

barley cultivars and legume species, as affected by soil phosphorus availability. Plant and Soil 427(1-2):125-138. DOI 10.1007/s11104-017-3365-z.

Demars BG. 1997. Foliar nutrient dynamics and resorption in naturalized lonicera maackii (caprifoliaceae) populations in ohio, usa. American Journal of Botany 84(1):112-117. DOI $10.2307 / 2445888$.

Dhillon J, Torres G, Driver E, Figueiredo B, Raun WR. 2017. World phosphorus use efficiency in cereal crops. Agronomy journal 109(4):1-8. DOI 10.2134/agronj2016.08.0483.

Dinkelaker B, Rmheld V, Marschner H. 2010. Citric acid excretion and precipitation of calcium citrate in the rhizosphere of white lupin (Lupinus albus L.). Plant Cell \& Environment 12(3):285-292. DOI 10.1111/j.1365-3040.1989.tb01942.x.

Djuniwati S, Pulunggono HB. 2019. The status of soil phosphorus at different cropping system in pangalengan, south bandung. Jurnal Ilmu Tanah dan Lingkungan 11(2):76-80. DOI 10.29244/jitl.11.2.76-80.

Du B, Ji H, Peng C, Liu X, Liu C. 2017. Altitudinal patterns of leaf stoichiometry and nutrient resorption in quercus variabilis in the baotianman mountains, China. Plant and Soil 413(12):193-202. DOI 10.1007/s11104-016-3093-9.

Fan J, Hao MD. 2003. Study on long-term experiment of crop rotation and fertilization in the loess plateau: i. effect of crop rotation and continuous planting on soil enzyme activities. Plant Nutrition and Fertilizer Science 9(1):9-13. DOI 10.11674/zwyf.2003.0102.

Fife DN, Nambiar EKS, Saur E. 2008. Retranslocation of foliar nutrients in evergreen tree species planted in a mediterranean environment. Tree Physiology 28(2):187-196. DOI 10.1093/treephys/28.2.187.

Foster NW, Bhatti JS. 2006. Forest Ecosystems: Nutrient Cycling. Rand Corporation, 1700 Main Street, Santa Monica, CA 90406. 718-721.

Gaiero JR, Bent E, Fraser TD, Condron LM, and Dunfield KE. 2018. Validating novel oligonucleotide primers targeting three classes of bacterial non-specific acid phosphatase genes in grassland soils. Plant and Soil 427(1-2):39-51. DOI 10.1007/s11104-017-3338-2.

Gaind S. 2016. Phosphate dissolving fungi: Mechanism and application in alleviation of salt stress in wheat. Microbiological Research 193:94-102. DOI 10.1016/j.micres.2016.09.005.

Garland G, Bünemann EK, Oberson A, Frossard E, Six J. 2017. Plant-mediated rhizospheric interactions in maize-pigeon pea intercropping enhance soil aggregation and organic phosphorus storage. Plant and Soil 415(1-2):1-19. DOI 10.1007/s11104-016-3145-1.

Githinji HK, Okalebo JR, Othieno CO, Bationo A, Kihara J, Waswa BS. 2011. Effects of conservation tillage, fertilizer inputs and cropping systems on soil properties and crop yield in western Kenya. In book: Innovations as key to the Green Revolution in Africa. pp: 281288. DOI 10.1007/978-90-481-2543-2-27.

Gordon WS, Jackson RB. 2000. Nutrient concentrations in fine roots. Ecology 81(1):275-280. DOI 10.2307/177151. 
595

596

597

598

599

600

601

602

603

604

605

606

607

608

609

610

611

612

613

614

615

616

617

618

619

620

621

622

623

624

625

626

627

628

629

630

631

632

633

634

Hallama M, Pekrun C, Lambers H, Kandeler E. 2019. Hidden miners-the roles of cover crops and soil microorganisms in phosphorus cycling through agroecosystems. Plant and Soil 434(1-2):7-45. DOI 10.1007/s11104-018-3810-7.

Herrera-Estrella L, López-Arredondo D. 2016. Phosphorus: the underrated element for feeding the world. Trends in Plant Science 21(6):461-463. DOI 10.1016/j.tplants.2016.04.010.

Heuck C, Weig A, Spohn M. 2005. Soil microbial biomass C:N:P stoichiometry and microbial use oforganic phosphorus. Soil Biology and Biochemistry 85:119-129. DOI 10.1016/j.soilbio.2015.02.029.

Hinsinger P, Betencourt E, Bernard L, Brauman A, Plassard C, Shen J, Zhang F. 2011. P for two, sharing a scarce resource: soil phosphorus acquisition in the rhizosphere of intercropped species. Plant Physiology 156(3):1078-1086. DOI 10.1104/pp.111.175331.

Hinsinger P, Plassard C, Tang C, Jaillard B. 2003. Origins of root-mediated $\mathrm{pH}$ changes in the rhizosphere and their responses to environmental constraints: a review. Plant and Soil 248(1-2):43-59. DOI 10.1023/a:1022371130939.

Hofmann K, Heuck C, Spohn M. 2016. Phosphorus resorption by young beech trees and soil phosphatase activity as dependent on phosphorus availability. Oecologia 181(2):369-379. DOI 10.1007/s00442-016-3581-x.

Hussain A, Adnan M, Hajira, Iqbal S, Fahad S, Saeed M, Mian IA, Muhammad MW, Romman M, Perveez R, Wahid F, Subhan F, Raza1 MA, Zamin M, Ullah F, Rehman K, Andaleeb S. 2019. Combining phosphorus (P) with phosphate solubilizing bacteria (PSB) improved wheat yield and P uptake in alkaline soil. Bolan Society for Pure and Applied Biology. 8(2):1809-1817. DOI 10.19045/bspab.2019.80124.

Ichriani GI, Syehfani, Nuraini Y, Handayanto E. 2018. Formulation of biochar-compost and phosphate solubilizing fungi from oil palm empty fruit bunch to improve growth of maize in an ultisol of central kalimantan. Journal of Ecological Engineering 19(6):45-55. DOI 10.12911/22998993/92891.

Jiang Y, Yin X, Wang F. 2013. The influence of litter mixing on decomposition and soil fauna assemblages in a pinus koraiensis mixed broad-leaved forest of the Changbai mountains, china. European Journal of Soil Biology 55:28-39. DOI 10.1016/j.ejsobi.2012.11.004.

Jones DL, Dennis PG, Owen AG, Hees PAWV. 2002. Organic acid behaviour in soilsmisconceptions and knowledge gaps. Plant and Soil 248(1-2):31-41. DOI 10.1023/a:1022304332313.

Juma NG, Tabatabai MA. 1977. Effects of trace elements on phosphatase activity in soils. Soil Science Society of America Journal 41(2):343-346. DOI 10.2136/sssaj1977.03615995004100020034x.

Karunakaran G, Suriyaprabha R, Manivasakan P, Yuvakkumar R, Rajendran V, Prabu P, Kannan N. 2013. Effect of nanosilica and silicon sources on plant growth promoting rhizobacteria, soil nutrients and maize seed germination. IET Nanobiotechnol 7(3):70-77. DOI 10.1049/iet-nbt.2012.0048.

Peer] reviewing PDF | (2021:01:56829:2:0:NEW 23 May 2021) 
635 Kobe RK, Lepczyk CA, Iyer M. 2005. Resorption efficiency decreases with increasing green

636

637

638

639

640

641

642

643

644

645

646

647

648

649

650

651

652

653

654

655

656

657

658

659

660

661

662

663

664

665

666

667

668

669

670

671

672

673

674 leaf nutrients in a global data set. Ecology 86(10):2780-2792. DOI 10.2307/3450704.

Krishnaraj PU, Dahale S. 2014. Mineral phosphate solubilization: concepts and prospects in sustainable agriculture. Proceedings of the Indian National Science Academy 80(2):389-405. DOI 10.16943/ptinsa/2014/v80i2/55116.

Kumar R, Shastri B. 2017. Role of phosphate-solubilising microorganisms in sustainable agricultural development. Agro-Environmental Sustainability pp 271-303. Springer International Publishing. DOI 10.1007/978-3-319-49724-2_13

Lajtha K. 1987. Nutrient reabsorption efficiency and the response to phosphorus fertilization in the desert Shrublarrea Tridentata (DC.) Cov. Biogeochemistry 4(3):265-276. DOI $10.2307 / 1468668$.

Lambers H, Atkin OK, Millenaar FF. 2002. Respiratory Patterns in Roots in Relation to Their Functioning. In book: Plant Roots: The Hidden Half. Edition: Third Chapter: Respiratory patterns in roots in relation to their functioning Publisher: Marcel Dekker, Inc. New York Editors: Y. Waisel, A. Eshel, U. Kafkaki. pp: 521-552. DOI 10.1201/9780203909423.pt6.

Li M, Cozzolino V, Mazzei P, Drosos M, Monda H, Hu Z, Piccolo A. 2018. Effects of microbial bioeffectors and $\mathrm{p}$ amendements on $\mathrm{p}$ forms in a maize cropped soil as evaluated by 31 P--NMR spectroscopy. Plant and Soil 427(1-2):87-104. DOI 10.1007/s11104-0173405-8.

Limpens J, Berendse F, Klees H. 2003. $\mathrm{N}$ deposition affects $\mathrm{n}$ availability in interstitial water, growth of sphagnum and invasion of vascular plants in bog vegetation. New phytologist 157(2):339-347. DOI 10.2307/1514040.

Liu CJ, Mou L, Yi JL, Wang J, Liu AX, Yu JF. 2019. The Eno gene of burkholderia cenocepacia strain 71-2 is involved in phosphate solubilization. Current microbiology 76:495-502. DOI 10.1007/s00284-019-01642-7.

Lu JY, Yang M, Liu MG, Yang HM. 2019. Leaf stoichiometry and resorption of $\mathrm{n}$ and $\mathrm{p}$ in lucerne at different growth stages under different water supplies. Journal of Plant Nutrition 42(5):1-11. DOI 10.1080/01904167.2019.1567776.

Mao R, Song CC, Zhang XH, Wang XW, Zhang ZH. 2013. Response of leaf, sheath and stem nutrient resorption to 7 years of $\mathrm{N}$ addition in freshwater wetland of northeast china. Plant and Soil 364(1-2):385-394. DOI 10.1007/s11104-012-1370-9.

Martinez OA, Crowley DE, Mora ML, Jorquera MA. 2015. Short-term study shows that phytate-mineralizing rhizobacteria inoculation affects the biomass, phosphorus (P) uptake and rhizosphere properties of cereal plants. Journal of Soil Science \& Plant Nutrition (15):153-166. DOI 10.4067/S0718-95162015005000013.

Mclaren TI, Mclaughlin MJ, Mcbeath TM, Simpson RJ, Smernik RJ, Guppy CN, Richardson AE. 2016. The fate of fertilizer $P$ in soil under pasture and uptake by subterraneum clover- a field study using 33p-labelled single superphosphate: international journal of plant nutrition, plant chemistry, soil microbiology and soil-born plant diseases. Plant and Soil 401(1-2):23-38. DOI 10.1007/s11104-015-2610-6. 
675 Mehta P, Sharma R, Putatunda C, Walia A. 2019. Endophytic fungi: role in phosphate

676

677

678

679

680

681

682

683

684

685

686

687

688

689

690

691

692

693

694

695

696

697

698

699

700

701

702

703

704

705

706

707

708

709

710

711

712 solubilization. In book: Multi-Stage and Multi-Time Scale Feedback Control of Linear Systems with Applications to Fuel Cells. pp:183-209. DOI 10.1007/978-3-030-03589-1_9.

Menezes-Blackburn D, Giles C, Darch T, George TS, Blackwell M, Stutter M, Brown L. 2018. Opportunities for mobilizing recalcitrant phosphorus from agricultural soils: a review. Plant and Soil 427(1-2):1-12. DOI 10.1007/s11104-017-3362-2.

Miao F, Li Y, Cui S, Jagadamma S, Yang G, Zhang Q. 2019. Soil extracellular enzyme activities under long-term fertilization management in the croplands of China: a metaanalysis. Nutrient Cycling in Agroecosystems 114:125-138. DOI 10.1007/s10705-01909991-2.

Monreal CM, Bergstrom DW. 2000. Soil enzymatic factors expressing the influence of land use, tillage system and texture on soil biochemical quality. Canadian Journal of Soil Science 80(3):419-428. DOI 10.4141/S99-088.

Nannipieri P, Giagnoni L, Landi L, Renella G. 2011. Role of phosphatase enzymes in soil. Phosphorus in Action Springer, Berlin, Heidelberg. pp: 215-243. DOI 10.1007/978-3-64215271-9_9.

Nassal D, Spohn M, Eltlbany N, Jacquiod S, Smalla K, Marhan S, Kandeler E. 2018. Effects of phosphorus-mobilizing bacteria on tomato growth and soil microbial activity. Plant and Soil 427(1-2):17-37. DOI 10.1007/s11104-017-3528-y.

Neset TS, Bader H, Scheidegger R, Lohm U. 2008. The flow of phosphorus in food production and consumption-linköping, sweden, 1870--2000. Science of the Total Environment 396(23):111-120. DOI 10.1016/j.scitotenv.2008.02.010.

Nriagu JO, Moore PH. 2012. Phosphate minerals. In Springer Science \& Business Media. DOI 10.1007/978-3-642-61736-2.

Nuccio E. 2014. Mapping soil carbon from cradle to grave: identifying the microbial blueprint for root-carbon transformations in soil. LBNL (Lawrence Berkeley National Laboratory (LBNL), Berkeley, CA (United States); DOE Joint Genome Institute (JGI).

Parfitt RL. 1989. Phosphate reactions with natural allophane, ferrihydrite and goethite. European Journal of Soil Science 40(2):359-369. DOI 10.1111/j.13652389.1989.tb01280.x.

Peñuelas J, Sardans J, Rivas-ubach A, Janssens IA. 2012. The human-induced imbalance between c, $\mathrm{n}$ and $\mathrm{p}$ in earth's life system. Global Change Biology 18(1):3-6. DOI 10.1111/j.1365-2486.2011.02568.x.

Rawat P, Das S, Shankhdhar D, Shankhdhar SC. 2020. Phosphate-Solubilizing Microorganisms: Mechanism and Their Role in Phosphate Solubilization and Uptake. Journal of Soil Science and Plant Nutrition 21:49-68. DOI 10.1007/s42729-020-00342-7.

Richardson AE. 2001. Prospects for using soil microorganisms to improve the acquisition of phosphorus by plants. Functional Plant Biology 28(9):897-906. DOI 10.1071/PP01093.

Peer) reviewing PDF | (2021:01:56829:2:0:NEW 23 May 2021) 
713

714

715

716

717

718

719

720

721

722

723

724

725

726

727

728

729

730

731

732

733

734

735

736

737

738

739

740

741

742

743

744

745

746

747

748

749

750

Richardson AE. Lynch JP, Ryan PR, Delhaize E, Smith FA, Smith SE, Oberson A. 2011. Plant and microbial strategies to improve the phosphorus efficiency of agriculture. Plant and Soil 349(1-2):121-156. DOI 10.1007/s11104-011-0950-4.

Robinson WD, Carson I, Ying S, Ellis K, Plaxton WC. 2012. Eliminating the purple acid phosphatase atpap26 in arabidopsis thaliana delays leaf senescence and impairs phosphorus remobilization. New Phytologist 196(4):1024-1029. DOI 10.1021/es2044745.

Rodriguez H, Vidal RF, González T, Bashan Y. 2006. Genetics of phosphate solubilization and its potential applications for improving plant growth-promoting bacteria. Plant and soil 287:15-21. DOI 10.1007/s11104-006-9056-9.

Rojas YP, Arias RM, Ortiz RM, Aguilar DT, Heredia G, Yon YR. 2019. Effects of native arbuscular mycorrhizal and phosphate-solubilizing fungi on coffee plants. Agroforestry Systems 93:961-972. DOI 10.1007/s10457-018-0190-1.

Rosling A, Midgley MG, Cheeke T, Urbina H, Fransson P, Phillips RP. 2016. Phosphorus cycling in deciduous forest soil differs between stands dominated by ecto- and arbuscular mycorrhizal trees. New Phytologist 209(3):1184-1195. DOI 10.1111/nph.13720.

Sakuraba Y, Piao W, Lim JH, Han SH, Kim YS, An G, Paek NC. 2015. Rice onac106 inhibits leaf senescence and increases salt tolerance and tiller angle. Plant Cell Phytologist 56(12):2325-2339. DOI 10.1093/pcp/pcv144.

Sattari SZ, Bouwman AF, Giller KE, Van Ittersum MK. 2012. Residual soil phosphorus as the missing piece in the global phosphorus crisis puzzle. Proceedings of the National Academy of Sciences 109(16):6348-6353. DOI 10.1073/pnas.1113675109.

Shafqat MN, Pierzynski GM, Xia K. 2009. Phosphorus source effects on soil organic phosphorus: a $31 \mathrm{p} \mathrm{nmr}$ study. Communications in Soil Science and Plant Analysis 40(1112):1722-1746. DOI 10.1080/00103620902895821.

Sharma SB, Sayyed RZ, Trivedi MH, Gobi TA. 2003. Phosphate solubilizing microbes: sustainable approach for managing phosphorus deficiency in agricultural soils. SpringerPlus 2(1):587. DOI 10.1186/2193-1801-2-587.

Smit AL, Bindraban PS, Schröder JJ, Conijn JG, Meer HGVD. 2009. phosphorus in agriculture: global resources, trends and developments: report to the steering committee technology assessment of the ministry of agriculture, nature and food quality, the netherlands, and in collaboration with the nutrient flow task group (NFTG), supported by DPRN (development policy review network) (No. 282). Plant Research International.

Spohn M, Carminati A, Kuzyakov Y. 2013. Soil zymography - A novel in situ method for mapping distribution of enzyme activity in soil. Soil Biology \& Biochemistry 58: 275-280. DOI 10.1016/j.soilbio.2012.12.004.

Staff TPO. 2014. Correction: relationship between the relative limitation and resorption efficiency of nitrogen vs phosphorus in woody plants. Plos One 9:e94515. DOI 10.1371/journal.pone.0094515. 
751

752

753

754

755

756

757

758

759

760

761

762

763

764

765

766

767

768

769

770

771

772

773

774

775

776

777

778

779

780

781

782

783

784

785

786

787

788

Steenbergh AK, Bodelier PL, Hoogveld HL, Slomp CP, Laanbroek HJ. 2011. Phosphatases relieve carbon limitation of microbial activity in baltic sea sediments along a redoxgradient. Limnology and Oceanography 56(6): 2018-2026. DOI 10.4319/lo.2011.56.6.2018.

Sundara B, Natarajan V, Hari K. 2002. Influence of phosphorus solubilizing bacteria on the changes in soil available phosphorus and sugarcane and sugar yields. Field Crops Research 77(1): 43-49. DOI 10.1016/S0378-4290(02)00048-5.

Syers JK, Johnston AE, Curtin D. 2008. Efficiency of soil and fertilizer phosphorus use: reconciling changing concepts of soil phosphorus behaviour with agronomic information. Food and Agriculture Organization of the United Nations Report. Rome. 18: 108-108. DOI library/library-home/en/.

Tang B, Zhang X, Yang X. 2015. Effects of tobacco garlic crop rotation and intercropping on tobacco yield and rhizosphere soil phosphorus fractions. Chinese Journal of Applied Ecology 26(7):1977-1984.

Tang L, Han W, Chen Y, Fang J. 2013. Resorption proficiency and efficiency of leaf nutrients in woody plants in eastern china. Journal of Plant Ecology 6(5): 408-417. DOI 10.1093/jpe/rtt013.

Teng Z, Chen Z, Zhang Q, Yao Y, Song MY, Li M. 2018. Isolation and characterization of phosphate solubilizing bacteria from rhizosphere soils of the Yeyahu Wetland in Beijing, China. Environmental Science and Pollution Research 26:33976-33987. DOI 10.1007/s11356-018-2955-5.

Toscano-Verduzco FA, Cedeo-Valdivia PA, Chan-Cupul W, Hernández-Ortega HA, Esaú ER, Galindo-Velasco E, Cruz-Crespo E. 2019. Phosphates solubilization, indol-3-acetic acid and siderophores production by Beauveria brongniartii and its effect on growth and fruit quality of Capsicum chinense. Journal of Horticultural Science and Biotechnology 95(2):1-12. DOI 10.1080/14620316.2019.1662737.

Uliassi DD, Ruess RW. 2002. Limitations to symbiotic nitrogen fixation in primary succession on the tanana river floodplain. Ecology 83(1): 88-103. DOI 10.2307/2680123.

Urte S, Colmsee C, Scholz U, Bräutigam A, Weber A, Zellerhoff N, Bucher M, Fahnenstich H, Sonnewald U. 2013. Adaptation of maize source leaf metabolism to stress related disturbances in carbon, nitrogen and phosphorus balance. Bmc Genomics 14(1):442-442. DOI: $10.1186 / 1471-2164-14-442$.

USGS. 2016. Mineral commodity summaries 2015. Reston, VA: USGS. DOI 10.3133/70140094.

Usuda H. 1995. Phosphate deficiency in maize.v. mobilization of nitrogen and phosphorus within shoots of young plants and its relationship to senescence. Plant and Cell Physiology 36(6):1041-1049. DOI 10.1093/oxfordjournals.pcp.a078846.

Vance CP, Uhde-Stone C, Allan DL. 2003. Phosphorus acquisition and use: critical adaptations by plants for securing a nonrenewable resource. New Phytologist 157(3):423-447. DOI 10.1046/j.1469-8137.2003.00695.x.

Peer) reviewing PDF | (2021:01:56829:2:0:NEW 23 May 2021) 
789

790

791

792

793

794

795

796

797

798

799

800

801

802

803

804

805

806

807

808

809

810

811

812

813

814

815

816

817

818

819

820

821

822

823

824

825

826

827

828

Veneklaas EJ, Lambers H, Bragg J, Finnegan PM, Lovelock CE, Plaxton WC, Raven JA. 2012. Opportunities for improving phosphorus-use efficiency in crop plants. New Phytologist 195(2):306-320. DOI 10.1111/j.1469-8137.2012.04190.x.

Venterink HO. 2011. Legumes have a higher root phosphatase activity than other forbs, particularly under low inorganic $\mathrm{p}$ and $\mathrm{n}$ supply. Plant and Soil 347(1-2):137-146. DOI 10.1007/s11104-011-0834-7.

Vergeer P, Rengelink R, Ouborg NJ, Roelofs JG. 2003. Effects of population size and genetic variation on the response of succisa pratensis to eutrophication and acidification. Journal of Ecology 91(4):600-609. DOI 10.1046/j.1365-2745.2003.00785.x.

Vergutz L, Manzoni S, Porporato A, Novais RF, Jackson RB. 2012. Global resorption efficiencies and concentrations of carbon and nutrients in leaves of terrestrial plants. Ecological Monographs 82(2):205-220. DOI 10.1890/11-0416.1.

Wang J. 2016. Retrospect and prospect of soil environmental protection research in China. Urban Construction Theory Research: Electronic Edition 6(008):6993-6993. DOI 10.3969/j.issn.2095-2104.2016.08.908.

Wang Y, Houlton BZ, Field CB. 2007. A model of biogeochemical cycles of carbon, nitrogen, and phosphorus including symbiotic nitrogen fixation and phosphatase production. Global Biogeochemical Cycles 21(1):1-15. DOI 10.1029/2006GB002797.

Wang ZN, Lu JY, Yang HM, Zhang X, Luo CL, Zhao YX. 2014. Resorption of nitrogen, phosphorus and potassium from leaves of lucerne stands of different ages. Plant and Soil. 383(1-2):301-312. DOI 10.1007/s11104-014-2166-x.

Wright IJ, Westoby M. 2003. Nutrient concentration, resorption and lifespan: leaf traits of australian sclerophyll species. Functional Ecology 17(1):10-19. DOI 10.1046/j.13652435.2003.00694.x.

Yong TW, Liu XM, Liu WY, Su BY, Yang WY. 2014. Effects of reduced N application rate on yield and nutrient uptake and utilization in maize-soybean relay strip intercropping system. The Journal of Applied Ecology 25(2):474-482. DOI 10.1109/ICNC.2009.52.

Zhan HQ, Yan SS, Wang JR, Ma CM, Gong ZP, Dong SK, Zhang QW. 2015. Effects of rice straw returning on activities of soil phosphatase and available $\mathrm{p}$ values in soil. Crop pp:7883. DOI 10. 16035/j. issn.1001-7283.2015.02.016.

Zhang EH. 2001. Effects of $\mathrm{p}$ application on root acid phosphates of crops in intercropping. acta botanica boreali-occidentalia sinica. Acta Botanica Boreali-Occidentalia Sinica 21(1):5358. DOI 10.3321/j.issn:1000-4025.2001.01.009.

Zhang Q, Xiong G, Li J, Lu Z, Li Y, Xu W, Xie Z. 2018. Nitrogen and phosphorus concentrations and allocation strategies among shrub organs: the effects of plant growth forms and nitrogen-fixation types. Plant and Soil 427(1-2):305-319. DOI 10.1007/s11104018-3655-0.

Zineb AB, Trabelsi D, Ayachi I. 2019. Inoculation with elite strains of phosphate-solubilizing bacteria enhances the effectiveness of fertilization with rock phosphates. Geomicrobiology 37(1):1-9. DOI 10.1080/01490451.2019.1658826.

Peer) reviewing PDF | (2021:01:56829:2:0:NEW 23 May 2021) 


\section{Figure 1}

\section{Figure 1. Utilization of soil residual P and its regulation.}

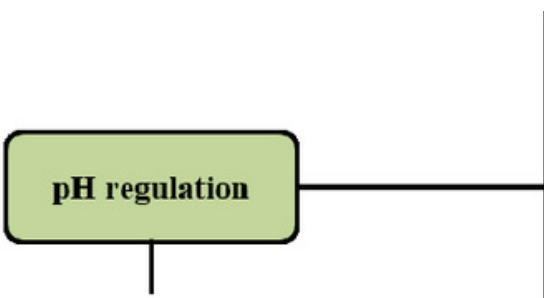

Rhizosphere acidification

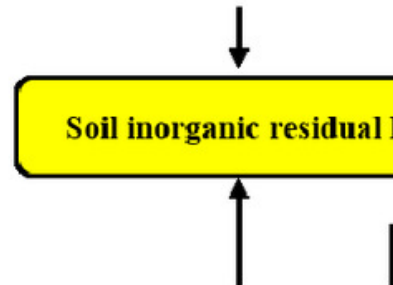

Exchange soil nutrient stoichiometric ratio

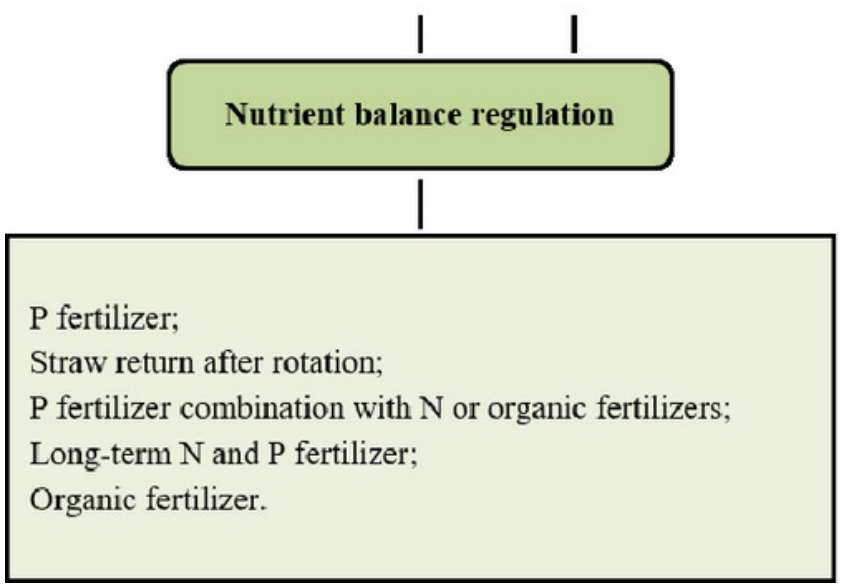

P fertilizer;

Straw return after rotation;

$\mathrm{P}$ fertilizer combination with $\mathrm{N}$ or organic fertilizers;

Long-term $\mathrm{N}$ and $\mathrm{P}$ fertilizer;

Organic fertilizer.
Fixed nitrogen plant;

Crops released organic acids, citric, oxalic and malic acids;

Cereals allocated more photosynthates to below-ground parts;

Crops that root-induced oxidation of $\mathrm{Fe}$;

$\mathrm{P}$ fertilizer combined with $\mathrm{N}$ or organic fertilizers.

Inoculate/addition phosphate-solubilizing microorganisms

Increase phosphatase activity

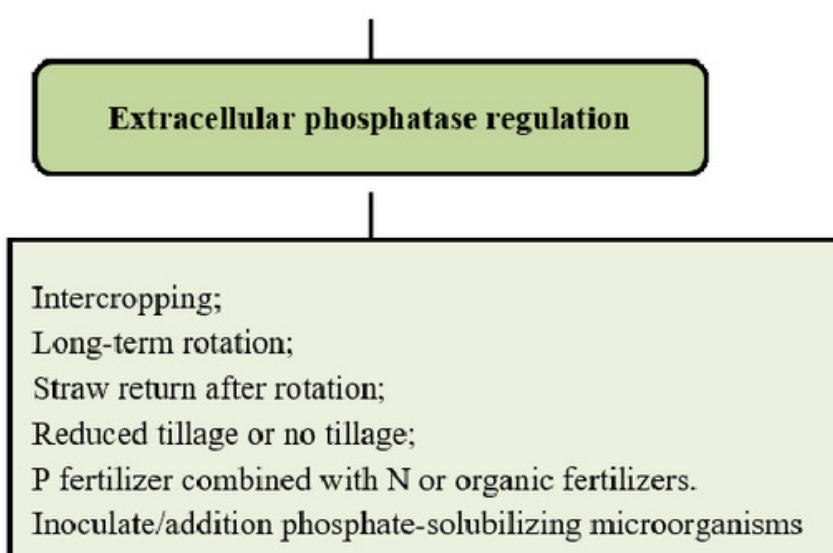

